\title{
Mucinous Bronchial Cell
}

National Cancer Institute

\section{Source}

National Cancer Institute. Mucinous Bronchial Cell. NCI Thesaurus. Code C33922.

A columnar epithelial cell found in the bronchi. It secretes mucus. 